\title{
MUNICIPAL FUNCTIONS AND THE LAW OF PUBLIC PURPOSE
}

\section{Charles M. KNeIER}

The extension of municipal activities in the United States presents both the question of policy and the question of legal power or right. The legal phase becomes of special significance as the city enters those fields of activity which are not strictly governmental but are rather corporate in their nature. The engagement of a city in such activities is attacked as being other than a proper municipal function, and as being taxation for other than a public purpose.

A consideration of the attitude of the courts towards this question shows a changing attitude, tending to become more liberal, due in part probably, to the need of meeting the changed conditions and problems of the time. The principle is established that a city can tax its inhabitants only for public purposes; taxation for other than public purposes is unconstitutional. ${ }^{2}$ While the courts are agreed that taxes may be levied only for public purposes, they are not agreed upon what principles to determine whether a thing is for a public purpose, and consequently they have been unable to agree whether certain things are, or are not, public purposes. They do seem to be fairly well agreed that it is not possible to lay down definite principles by which they may test each case as it arises to determine whether it is for a public purpose.

${ }^{1}$ Opinion of the Justices, I55 Mass. 598, 30 N. E. II42 (1892) ; Kingman v. City of Brockton, I53 Mass. 255, 26 N. E. 998 ( $189 \mathrm{r}$ ); Opinion of the Justices, I50 Mass. 592, 24 N. E. I084 (I890); Lowell v. Boston, III Mass. 454 (I873); State v. Osawkee Township, I4 Kan. 4I8 (I875); Mather v. City of Ottawa, II4 IIl. 659, 3 N. E. 216 (1885); Loan Association v. Topeka, 20 Wall. 655 (U. S. I875); Cole v. La Grange, I13 U. S. I (I885); Ottawa v. Cary, I08 U. S. IIo (I883); Attorney General v. Eau Claire, 37 Wis. 400 ( I875); State v. Eau Claire, 40 Wis. 533 (1876); Allen v. Jay, 60 Me. I24 (I872); Opinion of the Justices, $58 \mathrm{Me}$. 590 (I87I).

${ }^{2}$ Fallbrook Irrigation District v. Bradley, I64 U. S. II2 (I896) ; Strickley v. Mining Co., $200 \mathrm{U}$. S. 527 (1906); Jones v. City of Portland, 245 U. S. 2I7 (I917); Dodge v. Mission Township, I07 Fed. 827 (C. C. A. 8th, IgOI); Opinion of the Justices, Igo Mass. 6II, 77 N. E. 820 (I906); Coates v. Campbell, 37 Minn 498,35 N. W. 366 (I887); Woodall v. Darst, 7I W. Va. 350, 77 S. E. 264 (1913). 
In Loan Association v. Topeka, ${ }^{2 \mathrm{a}}$ Justice Miller, in considering whether a tax was for a public or private purpose, held that the courts "must be governed mainly by the course and usage of the government, the objects for which taxes have been customarily and by long course of legislation levied, what objects or purposes have been considered necessary to the support and for the proper use of the government, whether state or municipal." Judge Cooley in an opinion dealing with this question, held that "necessity is not the governing consideration" in considering whether taxation is for a public purpose. As applied to taxation, public purpose was held to have "no relation to the urgency of the public need, or to the extent of the public benefit which is to follow. It is, on the other hand, merely a term of classification, to distinguish the objects for which, according to settled usage, the government is to provide, from those which, by like usage, are left to private inclination, interest or liberality." 3 In both of these cases the court emphasizes settled usage in determining whether a tax is for a public purpose. But to follow precedent and allow only those things to be done which have been done in the past "would be essentially vicious and erroneous. Growth and extension are as necessary in the domain of municipal action as in the domain of law." " 4 It would be a narrow, if not dangerous, interpretation to put upon the fundamental law to hold that cities may employ only those methods and agencies which have proved adequate in the past. ${ }^{5}$

The question of whether a function is a public purpose "is a changing question, changing to suit industrial inventions and developments and to meet new social conditions." " For that reason it would be impossible to lay down with minute detail an

${ }^{2 s}$ Supra note $\mathrm{I}$.

${ }^{3}$ People v. Salem, 20 Mich. 452 (I870). In State v. Orear, 277 Mo. 303, 210 S. W. 392 (I919), the Supreme Court of Missouri said that the question of whether a business is public or private depends upon "whether such business is sanctioned by time and the acquiescence of the people as being public or private."

'Sun Printing \& Publishing Association v. New York, 8 App. Div. 230, 40 N. Y. Supp. 607 (I886); aff'd, I52 N. Y. 257,46 N. E. 499 (1897).

Ibid.

- City of Tombstone v. Macia, 245 Pac. 677, 680 (Ariz. I926). 
inexorable rule distinguishing public from private purposes. ${ }^{7}$ The Supreme Judicial Court of Maine has pointed out that times change and with them the wants and necessities of the people; "what was clearly a public use a century ago may, because of changed conditions, have ceased to be such today." The court went on to say that "what could not be deemed a public use a century ago may, because of changed economic and industrial conditions, be such today."

If a project is undertaken merely for gain or for private objects it is not for a public purpose; "Gain or loss may incidentally follow, but the purpose must be primarily to satisfy the need, or contribute to the convenience, of the people of the city at large."s Although the advancement of the public welfare may result incidentally, the promotion of the interests of individuals, either in respect of property or business, "is, in its essential character, a private and not a public object."

In view of the limitation of taxation only for a public purpose, how far have cities been allowed to assume proprietary functions and enter into the fields of private business? The municipal ownership of waterworks, ${ }^{9}$ and electric lighting plants ${ }^{10}$ have in practically all cases received the approval of the courts. The supplying by cities of their citizens with natural gas is also a public purpose for which the taxing power may be used. ${ }^{11}$ The Supreme Court of Ohio has held that "heat being an agent or principle indispensable to health, comfort, and convenience of every inhabitant of our cities" it cannot see why "through the

'Laughlin v. Portland, III Me. 486, 90 Atl. 3I8 (I9I4).

${ }^{8}$ Sun Printing, etc. v. New York, sitpra note 4.

'Reddall v. Bryan, I4 Md. 444 (I859); Omaha v. Omaha Water Co., 218 U. S. I80 (I9I0); Colby University v. Canandaigua, 69 Fed. 671 (N. D. N. Y. I895); Augusta v. Augusta Water District, Ior Me. I48, 63 Atl. 663 (Ig06).

${ }^{10}$ Linn v. Chambersburg, I60 Pa. 5II, 28 Atl. 842 (I894); Crawfordsville v. Braden, I30 Ind. I49, 28 N. E. 849 (I89I); Opinion of the Justices, I50 Mass. 592, $24 \mathrm{~N}$. E. 1084 (I890); Thompson Houston Electric Co. v. City of Newton, 42 Fed. 723 (S. D. Iowa 1890); Jacksonville Electric Light Co. v. City of Jacksonville, 36 Fla. 229, I8 So. 677 (I895). Contra: Mauldin v. Greenville, 33 S. C. I, II S. E. 434 (1890).

"Hamilton Gaslight \& Coke Company v. City of Hamilton, I46 U. S. 258 (1892); Indianapolis v. Consumers' Gas Trust Co., I44 Fed. 640 (C. C. A. 7 th, 1906); Opinion of the Justices, supra note Io. 
medium of natural gas, it may not be as much a public service to furnish it to the citizens as to furnish water." 12

The right of a city to operate a street railway has also been questioned as not being a public purpose. The courts have, however, held that "the means of transportation for people at large is a matter of public interest" 13 and a "city purpose," 14 and a proper municipal function. ${ }^{15}$ The right of the city of Cincinnati to tax the property of its citizens to construct The Cincinnati Southern Railway was upheld even though it extended several hundred miles in length. ${ }^{16}$ An underground street railway is a public purpose $;^{17}$ the same principle has been held to apply to the construction of a subway, which, when completed, was to be leased to a street railway company. ${ }^{18}$

Other proper municipal functions are the ownership and operation of ferries, ${ }^{19}$ wharves, ${ }^{20}$ and municipal markets. ${ }^{21}$ Where the activity has as its end the promotion of the health or general welfare the function is more clearly a public purpose $;^{22}$ this would justify the municipal ownership of a hospital. ${ }^{23} \mathrm{~A}$ statute has also been upheld which authorized cities to provide public baths and "to establish rates for the use of such baths." 24

${ }^{12}$ State v. Toledo, 48 Ohio II2, 26 N. E. I06I (I89I); also see State v. City of Hamilton, 47 Ohio 52, 23 N. E. 935 (I895).

${ }^{13}$ Opinion of the Justices, 23I Mass. 603, I22 N. E. 763 (I9I9).

"Sun Printing, etc. v. New York; supra note 4; City of New York v. Brooklyn City R. R., 232 N. Y. 463, I34 N. E. 533 (I922).

${ }^{15}$ Platt v. San Francisco, 158 Cal. 74, IIo Pac. 304 (Igro); State v. Weiler. IOI Ohio I23, I28 N. E. 88 (I920); Tulloch v. City of Seattle, 67 Wash. I78, 124 Pac. 48I (I9I2) (Held invalid on other grounds).

${ }^{10}$ Walker v. Cincinnati, 2I Ohio I4 (187r).

${ }^{17}$ Sun Printing, etc. v. New York, supra note 4.

${ }^{13}$ Prince v. Crocker, I66 Mass. 347, 44 N. E. 446 (I896) ; Brown v. Turner, 176 Mass. 9, 56 N. E. 969 (I900); Admiral Realty Co. v. City of New York, 206 N. Y. Iro, 99 N. E. 24I (IgI2).

${ }^{10}$ Attorney General v. Boston, I23 Mass. 460 (I877).

${ }^{20}$ Hafner v. St. Louis, I6r Mo. 34, 6r S. W. 632 (Igor) ; Nicholls v. Charlevoix Circuit Judge, 155 Mich. 455, I20 N. W. 343 (1909).

^ Spaulding v. Lowell, 40 Mass. 7I (1839); Bank v. Bell, 62 Cal. App. 320, 217 Pac. 538 (I923).

$\approx$ Several cities own abattoirs.

${ }^{23}$ State v. Madison, 7 Wis. 688 (1858); Allentown v. Wagner, 214 Pa. 210, 63 Atl. 697 (1906).

${ }^{24}$ Bolster v. Lawrence, 225 Mass. 387, II4 N. E. 722 (I917). 
Municipally owned swimming pools, at which charges are made, are now quite common, the question of their being for a public purpose not seeming to have arisen.

A municipal function concerning which the question of public purpose has had a more important part is that of fuel yards. In the earlier cases which were brought before the courts it was held that a city could not engage in the sale of fuel as it was a commodity which was, and could be, easily furnished by private competitive. enterprise. The Supreme Judicial Court of Massachusetts, in an advisory opinion rendered in 1892 , held that it was unaware of any necessity why cities and towns should undertake this form of business, any more than many others which had always been conducted by private enterprise. $^{25}$ In an opinion handed down in I903, the court reiterated this point of view, but held that where, by reason of the supply of fuel being so small and the difficulty of obtaining it so great, persons desiring it were unable to supply themselves through private enterprise, the city could constitute itself an agent for the relief of the community, and money expended for that purpose would be for a public use. ${ }^{26}$ The Michigan Supreme Court in I906 refused to uphold the power of a city to engage in the coal business even in case of emergency; such use of the money of the city was not for a public purpose. ${ }^{27}$ The unlawful conduct of coal dealers to enhance, regulate, and control the price of coal was not accepted as an excuse for the city entering this new field of activity. While a city might provide coal for its needy citizens, where, as in this case, a coal famine appeared imminent, it could not enter into a commercial enterprise, such as buying and selling coal to its citizens as a business, thereby entering into competition with dealers in coal.

Later decisions of the courts seem to have established the

${ }^{25}$ Opinion of the Justices, I55 Mass. 598, 30 N. E. II42 ( I892). Justice Oliver Wendell Holmes, later of the United States Supreme Court, dissented, holding that fuel was an article of public necessity and could be so supplied.

${ }^{23}$ Opinion of the Justices, I82 Mass. 605,66 N. E. 25 (I903). A dissenting opinion refused to accept the emergency exception.

${ }^{2 \pi}$ Baker v. City of Grand Rapids, I42 Mich. 687, I06 N. W. 208 (Ig06). 
principle that cities may establish and operate fuel yards. ${ }^{28}$ The Supreme Judicial Court of Maine in a case before it in I9I4 reasoned that if a city can have a central gas, electric, or heating plant, it can sell heat in another form, namely coal; "it is only a different and simpler mode of distribution." 29 The court laid down two tests of a public purpose: first, the subject matter, or commodity, must be one of "public necessity, convenience, and welfare," second, the difficulty of individuals in providing it for themselves. In the case of fuel, the practical difficulty laid down in the second test was caused by the existence of monopolistic conditions. The argument was made before the court that if a city can establish a fuel yard it could enter upon any kind of commercial enterprise and carry on a grocery store, or a meat market, or a bakery. The court said that this did not follow for two reasons: first, fuel was an indispensable necessity of life for which there were no substitutes; and in the second place, under present economic conditions the other things were regulated by competition, but in the case of a fuel yard, "The element of commercial enterprise is entirely lacking." 30

The question was later brought before the Supreme Court of the United States which upheld the right of municipalities to establish fuel yards. ${ }^{31}$ The court pointed out that while ultimate authority to determine the validity of legislation under the Fourteenth Amendment rested in it, local conditions were of such varying character that "what is or what is not a public use in a particular state is manifestly a matter respecting which local authority, legislative and judicial, has peculiar facilities for securing accurate information;" for that reason, "the judgment of the highest court of the state upon what should be deemed a public use in a particular state is entitled to the highest respect"

${ }^{23}$ In Consumers' Coal Co. v. City of Lincoln, rog Neb. 5I, I89 N. W. 643 (I922), the Supreme Court of Nebraska, while holding the maintenance of a fuel yard to be a public purpose, held that the establishment of such was not within the powers granted to the council of the city of Lincoln. The case was a question of the interpretation of the home rule charter of the city.

$\approx$ Laughlin v. Portland, supra note 7.

${ }^{20}$ The right of a city to establish a fuel yard was again upheld in Jones v. Portland, II3 Me. I23, 93 Atl. 4I (IgI5).

31 Jones v. Portland, supra note 2. 
and a decision of the highest court of a state, declaring a use to be public in its nature is accepted unless clearly not well founded. ${ }^{32}$ With this in view, the court was unable to say that the statute under consideration violated rights of the taxpayer by taking his property for uses which were private. ${ }^{33}$

This question was before the Supreme Court of Minnesota in 1922. ${ }^{34}$ The right of municipalities to own and operate fuel yards was upheld, the court pointing out that many municipal activities, the propriety of which is not now questioned, were at one time thought, and rightly so, to be of a private character, . . "The constitutional provision that taxes can be levied only for public purposes remains; but conditions which go to make a purpose public change." 35

Another municipal function upon which the courts are not agreed as to whether it is a public purpose is that of operating ice plants. The question was first presented to the Supreme Court of Georgia in I910; ${ }^{36}$ the right of a city to operate an ice plant was upheld as being a public purpose. The court reasoned that if it was a public purpose for a city to furnish heat to its citizens in a cold climate it was just as much a public purpose to furnish ice in a hot climate. It was also pointed out that if a city may furnish water and still be for a public purpose, it can furnish ice, which is water in a frozen condition. ${ }^{37}$ In answer

${ }^{32}$ Fallbrook Irrigation District v. Bradley, supra note 2; Clark v. Nash, I98 U. S. 36T (r905).

${ }^{33} 245$ U. S. 2 I7 (IgI7). (rg22).

${ }^{34}$ Central Lumber Co. v. City of Waseca, I52 Minn. 201, I88 N. W. 275

${ }^{35}$ Ibid.

${ }^{36}$ Holton v. City of Camilla, I34 Ga. 560, 68 S. E. 472 (Igro). Also see Saunders v. Mayor, etc., Town of Arlington, I47 Ga. 58I, 94 S. E. I022 (r9I8), where the right of a city to establish an ice plant was upheld under a charter provision which permitted it to issue bonds for making certain enumerated and "other public improvements."

${ }^{37}$ Justice Timlin, of the Supreme Court of Wisconsin, in the case of State v. Thompson, 149 Wis. $488, x_{37}$ N. W. 20 (I9I2), in a concurring opinion, criticized the frozen water analogy as follows: "But things which are similar from a physical or chemical viewpoint may be dissimilar from the legal viewpoint; under a statute authorizing a city to buy coal it probably could not buy diamonds, although it is said they are chemically identical." The court in this case refused to uphold the right of Milwaukee to establish an ice plant but not on the grounds of not being for a public purpose. 
to the objection that the city would be engaging in manufacturing, the court asked if it might not "perhaps equally as well be said to be manufacturing when by the use of a filtering process it changes impure water into that which is pure." When, in connection with a waterworks system a city produces ice, "it merely, by certain processes, changes the form and temperature of a part of the water supplied by that system."

The Supreme Court of Louisiana refused to uphold the operation of an ice plant under a state constitutional provision that the power of taxation could be exercised by municipalities only for purposes "strictly public in their nature." 38 The court refused to accept the frozen water argument of the Supreme Court of Georgia since "all analogy between the municipal distribution of water and the municipal distribution of ice is destroyed by the fact that for the one business pipes have to be laid in the public streets, and, necessarily, for doing this, the streets have to be torn up and disturbed, whereas the other is a purely competitive business enterprise." The court held that the analogy would be complete if the city gave up the distribution of water by pipes and peddled the water; "but everybody would then see that the town was no longer discharging a sovereign function, but carrying on a private enterprise."

The right of a city to manufacture and sell ice to its inhabitants has also been upheld by the Supreme Court of Arizona. $^{39}$ The court pointed out that many parts of Arizona have a climate "almost tropical," and referring to the Maine fuel yard case, held that if heat was necessary to the health, comfort, and convenience of the people of the cities of that state, ice was no less so to the inhabitants of the cities of Arizona.

The Supreme Court of Missouri has, however, refused to uphold the power of cities of that state to maintain ice plants under a constitutional provision that "Taxes may be levied and collected for public purposes only." 40 The court, to determine

${ }^{28}$ Union Ice \& Coal Co. v. Town of Ruston, I35 La. 898, 66 So. 262 (I9I4).

$\approx$ Tombstone v. Macia, supra note 6.

${ }^{10}$ State v. Orear, sucpra note 3. In State v. Port of Seattle, ro4 Wash. 634 , I77 Pac. 67I (I919), it was held that the port of Seattle had no authority 
whether the maintenance of an ice plant was for a public purpose invoked the rule of "whether such business is sanctioned by time and the acquiescence of the people as being public or private." Judged by this standard, the court held that the making and selling of ice by Kansas City to its inhabitants, was not so far a public purpose as to warrant the expenditure of public money obtained from the sale of municipal bonds, "the payment of which, with the interest thereon, must be met by the levy and collection of public taxes." Ice has but recently, if as yet, been promoted to a place among the necessities of life according to the holding of the court; "time was but recently when it was considered as a luxury only." The court went on to say that even though it has now become a necessity of life "it is as yet certainly no greater a necessity to the human race than are food and clothing." Since, according to the court, no one would hesitate to say that the latter were not public purposes which the city could spend money for, it held that an ice plant was as yet in the same class.

These decisions of the highest courts of the states show that they are not agreed as to whether the operation of an ice plant is a proper municipal function. It seems that this is a question which might depend upon local conditions; it might be a public purpose in Arizona with a "climate almost tropical" and not public in a state where, on account of the different climatic conditions, ice is not such a necessity of life. It may be expected that when the question is brought before the Supreme Court of the United States, it will follow the principle of giving the highest respect to the judgment of the highest court of the state "upon what should be deemed a public use in a particular state." 41

The right of cities to build and rent buildings, or parts thereof, has also been questioned as being a proper municipal function, involving taxation for other than a public purpose. In determining in a given case whether the erection of a building

under the laws creating it to engage in the manufacture and sale of ice. The decision was made upon the interpretation of the law rather than upon the question of being for other than a public purpose.

¿ 245 U. S. 217 (1917). 
is a proper municipal function, the courts consider whether the dominating motive for the erection is a strictly public use. If so, the expenditure for it is legal, although incidentally it may be devoted occasionally to uses which are not public. ${ }^{42}$ In the case of a public hall, the Supreme Judicial Court of Massachusetts has pointed out that if, however, the project of a city is merely colorable, masking under the pretext of a public purpose, a general design to enter into the private business of maintaining a public hall for gain, or devoting it mainly to any other than its public use as a gathering place for citizens generally, such an attempt would be a perversion of power and a nullity and no public funds could be appropriated for it. ${ }^{43}$ The city may rent part of a building where it conceives that by doing this it may lighten its burden in the erection of a new building; however, it has no right as a primary purpose to build buildings to rent. ${ }^{44}$ The distinction drawn by the atthorities is as to the primary object of the public expenditure in the erection of the building; the fact that there is an added expense in the erection of a building, which standing alone would be unlawful, does not make the expenditure illegal as not being for a public purpose if the primary object of the building is to subserve a proper public purpose. ${ }^{45}$

While a city may not erect buildings for business or speculative purposes, where it has a city hall built in good faith and used for municipal purposes, it has the right to allow it to be used incidentally for other purposes. ${ }^{46}$ It is no valid objection to the exercise of the municipal powers that the public will not make exclusive use of the building. ${ }^{47}$ The Supreme Judicial Court of Maine has held that a town did not exceed its powers in mak-

\footnotetext{
${ }^{42}$ Wheelock v. City of Lowell, I96 Mass. 220, 8I N. E. 977 (1907).

${ }^{3}$ Ibid.

"Bates v. Bassett, 60 Vt. 530, I5 Atl. 200 (I888); White v. Stamford, 37 Conn. 578 ( 187 I).

Ibid.

${ }^{46}$ Worden v. New Bedford, I3I Mass. 23 (I88I); also see Bell v. Platville, $7 \mathrm{I}$ Wis. $139,36 \mathrm{~N}$. W. $83 \mathrm{I}$ (I888).

${ }^{47}$ Denver v. Hallett, 34 Colo. 393, 83 Pac. 1066 (1905); also see Egan v. City and County of San Francisco, I65 Cal. 576, I33 Pac. 294 (1913); Wilkerson v. City of Lexington, I88 Ky. 381, 222 S. W. 74 (I920); State v. Barnes, 22 Okla. I9I, 97 Pac. 997 (1908).
} 
ing a contract to allow a dramatic company the use of its town house for a period of six years, when not wanted for town purposes, in consideration of money to be expended by the company in enlarging the building and putting upon it necessary repairs. ${ }^{48}$ The court reasoned that the expenditure of money in building the hall was not to afford encouragement to a dramatic company, but the end to be attained was to get an improved town hall, and the contract with the dramatic company was designed as a means by which it could be accomplished. Since this mode decreased the amount of money to be raised, it could not be considered as the expenditure of money primarily for an opera house.

The Supreme Court of Iowa has held that an incorporated city of twelve hundred population, located in a farming community, has no power to erect a city building designed for an opera house with an auditorium, box office, ticket window, stage, balcony, dressing rooms, etc., even though of the floor space of about six thousand square feet, twelve hundred square feet were to be used by the city government for offices, fire department, etc. ${ }^{49}$ The court held that the building was primarily an opera house; "The town offices and the place for the fire department were mere incidents to the building." However desirable it might be for rural towns to have a large assembly hall or opera house, "it is not within the power of the town council to build it." The question of policy was also considered by the court which pointed out that because of the liability which would be attached to the operation of an opera house, "it is a burden which should not be assumed."

While a city or town may acquire and hold such real estate as may be necessary to enable it to carry on its corporate business and exercise its proper municipal functions, "it is idle to claim that a municipal corporation can lawfully engage in the business of buying, selling, or dealing generally in real estate, either as principal or broker." 50 A city can acquire property for cor-

\footnotetext{
${ }^{4 s}$ Jones v. Sanford, $66 \mathrm{Me} .585$ (1877).

${ }^{4}$ Brooks v. Town of Brooklyn, I46 Iowa I36, I24 N. W. 868 (I910).

${ }^{50}$ Hayward v. Board of Trustees of Town of Red Cliff, 20 Colo. 33, 36 Pac. 795 (1894).
} 
porate purposes only and cannot embark in "speculative ventures," or make any contracts in the nature of "mere investments." 51

Since, as the above cases indicate, a city cannot build buildings where the primary object in view is the rental of them to individuals, may it go into the "building and loan" business to the extent of lending money to others to build and develop the city? The decision of the Supreme Judicial Court of Massachusetts in Lorell $v$. Boston, ${ }^{52}$ holding unconstitutional a statute of 1872 , authorizing the city of Boston to issue bonds and lend the proceeds on mortgage to the owners of land, the buildings upon which were burned by the great fire of that year, indicates that this could not be done. "The expenditure authorized by the statute being for private and not for public objects, in a legal sense, it exceeds the constitutional power of the Legislature; and the city cannot lawfully issue the bonds for the purposes of the act," according to the decision of the court. ${ }^{53}$ But as in the case of other municipal functions, "times change" and while this activity was frowned upon by these earlier decisions, it is possible that, on account of the changed economic conditions, this may become a proper municipal activity.

A decision of the Supreme Court of Washington upholding an act authorizing the raising of funds by taxation for the purchase, improvement and settlement of undeveloped agricultural lands to be sold later by the state to private individuals indicates that it might be constitutional for a city to develop sections of the city and sell to private individuals. ${ }^{54}$ The Washington court held that the act of the legislature of that state was not unconstitutional as levying a tax for other than a public purpose.

${ }^{81}$ Hunnicutt v. City of Atlanta, 104 Ga. I, 30 S. E. 500 (1898).

sz III Mass. 454 (1873).

${ }^{53}$ Also see Opinion of the Justices, 2II Mass. 624, 98 N. E. 6II (IgI2). L. D. Upson, Practice of Munictpat Administration (Ig26) 568, states that the city of Milwaukee owns stock in the Garden Homes Company which is building and disposing of houses at low prices and easy terms. The city of Los Angeles is also authorized to do this by its new charter.

"State v. Clausen, Iro Wash. 525, I88 Pac. 538 (I920). Two of the Justices dissented on the grounds that this "attractive bit of paternalistic legislation" was not for a public purpose. 
The acquisition of golf courses by cities has also been attacked before the courts as being taxation for other than a public purpose. The Supreme Court of Oregon has held that the city of Portland may acquire a golf links, it being a "public utility" within the meaning of the charter of that city. ${ }^{55}$ The right of Minneapolis to acquire a golf course under the home rule act of that state authorizing cities to take property "needed for the full discharge of any public function which it is permitted to exercise," has been upheld by the Supreme Court of Minnesota. $^{56}$

A new problem arose in the case of the municipally owned golf course in Louisville, Kentucky. ${ }^{5 \tau_{5}}$ The city hired a golf professional, and to induce him to take the position, and for the convenience of the golf players, provided a place at the golf course in which to clean and repair clubs, and the professional was given the privilege of selling golf balls, golf clubs, and other golf equipment. The merchants in Louisville brought action to enjoin the board of park commissioners from permitting the sale of these articles, it being pointed out that the Louisville merchants were not able to compete with the sale at the municipal course since the latter had no rent to pay. Was it a proper municipal function for a city to engage in the sale of golf equipment in connection with a municipal golf course? The Supreme Court of Kentucky upheld the right of the city of Louisville to provide for the sale of this material as being within the purview of "park purposes ;" the park board not only had the authority to maintain the golf course but to do "those things which are reasonably necessary for its proper enjoyment by the public." Since the golf course was three and one-half miles from the business part of Louisville and to go from the golf course down town to get anything needed and come back would take from forty to sixty minutes ordinarily, the court considered this new function to be reasonably necessary for the proper enjoyment of the golf course by the public.

\footnotetext{
${ }^{55}$ Capen v. City of Portland, I12 Ore. 14, 228 Pac. I05 (1924).

${ }^{56}$ Boot v. Minneapolis, I63 Minn. 223, 203 N. W. 625 (I925).

${ }^{57}$ Sutcliffe Co. v. City of Louisville, 205 Ky. 718, 266 S. W. 375 (Ig24).
} 
The question of the public purpose of various other municipal functions has also been before the courts. The Supreme Court of Ohio, in a case before it in $\mathrm{IgI}^{\mathrm{I}} 3$, in considering whether the city of Toledo could own and operate a moving picture theatre, pointed out that while it was primarily a question under the Ohio home rule provision, that is, whether the establishment and operation of a moving picture show is within "the powers of local self-government," the question as to whether this was a proper governmental function was also involved. ${ }^{58}$ The court held that it would be an unauthorized use of public money to acquire a moving picture theatre since property may be taken only for uses which are public, and little protection of property rights would be left "if the proceeds of thrift and industry may be seized for the establishment and operation of moving picture shows and all other imaginable purposes not more frivolous nor more remote from the functions of government." It has also been held that the expenditure of public money for a hockey rink to be used by a closely allied athletic association for playing hockey games between salaried teams and where there was to be an admission charge was not a public purpose. ${ }^{59}$

The Supreme Judicial Court of Maine in an advisory opinion handed down in $187 \mathrm{I}$ replying to the question as to whether towns might "establish manufactories entirely on their own account, and run them by the ordinary town officers" replied that it could not be done. ${ }^{60}$ It was pointed out by the court that "Towns are public corporations, created and existing only for public purposes, not private corporations for the purpose of traffic or manufacturing."

The Supreme Court of South Dakota has upheld the power of the city of Mitchell to sell bonds for the construction and installation 'of a telephone system. ${ }^{01}$ In upholding the right of the city to assume this new function the court said that the test as to whether taxes could be raised for this purpose and as to

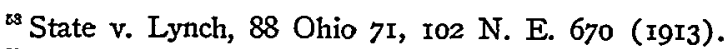

${ }^{\infty}$ Burns v. Essling, I56 Minn. I7I, I94 N. W. 404 (I923).

${ }^{\infty}$ Opinion of the Justices, $58 \mathrm{Me}$. 590 (I87I).

at Spangler v. City of Mitchell, 35 S. D. 335, I52 N. W. 339 (I915).
} 
whether it could be made the subject of municipal ownership and control "is, not whether such service is necessary as an exercise of the functions of municipal government, but whether it is a public service."

The question was presented to the Supreme Court of Georgia, in a case before it in $I 897$, as to whether a city might operate a plumbing supply store. ${ }^{62}$ The city of Waycross claimed that the power to do this was implied in its right to operate a water works. The city had purchased plumbing supplies and furnished materials to, and had work done, for such of its citizens as had applied to it to have fixtures and pipes placed in and upon their premises. The city had realized a "reasonable profit" from this work. Since the city could not show express legislative authority to engage in the plumbing business such implied power was denied. This, in the "absence of express legislative sanction," a municipal corporation was held to have "no authority to engage in any independent business enterprise or occupation such as is usually pursued by private individuals. In other words, its legitimate duty is to deal with public affairs, and not those which are purely private and entirely unconnected with a proper administration of its governmental duties." Since the power had not been given, the court did not find it necessary to answer this question; it seems very questionable whether this would be considered a public purpose even though the power was given. While it would probably be considered to be a necessity of modern life, it seems as if it cannot be said that it is not possible to depend upon competitive industry for its supply.

A question which has recently been presented to the courts is as to whether a city may engage in the sale of gasoline by the operation of a municipal gasoline filling station. ${ }^{63}$ In I924 the city of Lincoln, Nebraska, adopted an amendment to its home rule charter which provided that the city council have the power to

Keen v. Waycross, 1or Ga. 588, 29 S. E. 42 (1897).

"s Standard Oil Co. v. City of Lincoln, II4 Neb. 243,207 N. W. I72 (I926). The United States District Court for the District of Nebraska, for the Lincoln Division, had held in a case before it in 1925 that the sale of gasoline was a proper function of local government. Mutual Oil Co. v. Zehrung, Ix F. (2d) 887 (D. C. Neb. I925). 
engage in the.business of selling gasoline and oil to the inhabitants of the city, both at retail and wholesale. The amendment further provided that the city should not charge for gasoline and oil sold by it, more than the cost thereof to the city, plus the cost of handling the same, including contingencies. Pursuant to this amendment the city council adopted an ordinance creating a municipal gasoline department for the sale of gasoline and oil and provided that gasoline be sold to the inhabitants of the city at cost.

The right of the city to sell gasoline and oil was questioned on the grounds, among others, that it deprived private dealers of their property without due process of law since the city was using public money derived from taxation to carry on the business, and that the money so used was for a private purpose and not for a public purpose. The private dealers argued that the money so used by the city was not for a public purpose but solely for the benefit of the purchasers of gasoline and oil. In upholding the right of the city to sell gasoline, the Supreme Court of Nebraska gave much weight to the decision of the Supreme Court of the United States in the case of Green v. Frazier, ${ }^{64}$ where the acts of the legislature of the state of North Dakota providing for the establishment of a state bank, a line of warehouses and elevators, flour mills and manufacturing establishments, and for the handling of wheat and the manufacture of flour, and even to the establishment of a home-building association were held to be not in contravention of the Fourteenth Amendment. The Supreme Court had held in that case that "when a state sees fit, for the promotion of the public welfare, to enter into activities which in the past have been considered as entirely within the domain of private enterprise and to assist them by taxation, the wisdom of its legislation or soundness of the economic policy involved cannot be considered by this court in passing upon the constitutionality of the taxation."

The Nebraska court, in considering the argument made that the business of selling gasoline had "never been affected with a public interest" and is now a "purely private business, and uni-

253 U. S. 233 (1920). 
versally recognized as a proper and legitimate field for private enterprise," pointed out that "gasoline has become one of the indispensable commercial commodities of our time." A commodity of so universal use was held to come within the purview of "public purpose" as distinguished from "private purpose" and the city in engaging in the business violated neither the Fourteenth Amendment of the Federal Constitution nor any provision of the state constitution. ${ }^{65}$

The case was appealed to the Supreme Court of the United States which, in a decision handed down in December, I927, affirmed the decision of the Supreme Court of Nebraska. ${ }^{65 a}$ The case was disposed of, without a written opinion, on the authority of the decisions in Jones $v$. City of Portland, 245 U. St 2 I 7 (I9I7), and Green v. Frazier, 253 U. S. 233 (I920). In those cases the court had stated that great weight would be given to the fact that a state had authorized a municipality to tax with a view to providing a service and that purpose had been declared by the highest court of the state to be a public one. Evidently the court was unable to see any "demonstrated usurpation of power" having "no reasonable relation to the execution of lawful purposes" which would justify judicial interference.

The consideration of these cases shows the gradual extension of the law of public purpose as applied to municipal functions. Things formerly felt to be entirely within the domain of private competitive enterprise are now being assumed by municipalities as a proper governmental function. The usual attack made upon such increased activity is that in using money raised by taxation for such use, it is for other than a public purpose and consequently unconstitutional. The courts in deciding upon the le-

(5) In White Eagle Oil \& Refining Co. v. Gunderson, 205 N. W. 6I4 (S. D. r925), where the question of the right of the state of South Dakota to engage in the sale of gasoline was presented to the Supreme Court of that state, it was held that taxation for this purpose was unconstitutional. The court held that there was nothing essentially different in the business of retailing gasoline from that of any other commodity and "while it may be conceded that gasoline under present economic conditions is a necessity, there is no reason why it may not be retailed by private enterprise." To use money derived from state taxation to engage in such enterprise was held to contravene that provision of the state constitution providing that "Taxes . . . shall be levied and collected for public purposes only."

${ }^{65}$ Standard Oil Co. v. City of Lincoln, decided Dec. 5, I927. 
gality of such functions have taken what might be termed a liberal or progressive attitude. They have not arbitrarily refused to permit a thing at a later date because at some earlier time it had been held to be other than a legitimate public purpose. Public purpose as applied to taxation is a changing concept. It is fortunate that the courts have not placed a narrow interpretation upon the law of public purpose but have been cognizant of the fact that times change.

The question arises as to the future of municipal functions from the point of view of the law of public purpose. If a city may engage in the sale of gasoline to its inhabitants, what are the limits beyond which it may not go? Why may it not enter upon any kind of commercial enterprise and operate a grocery store or a meat market or a bakery? The Supreme Judicial Court of Maine has laid down two tests of public purpose, which have been accepted by the Supreme Court of the United States: is the article a necessity of life, and is it, under present economic conditions not regulated by competition in the ordinary channels of private business enterprise? It seems questionable whether the sale of gasoline measures up to these two tests. Even though it is granted that it is a necessity of life, can it be said that gasoline is not "under present economic conditions, regulated by competition in the ordinary channels of private business enterprise."

The object in establishing a municipal gasoline station to sell gasoline at cost would quite probably be to reduce prices charged by private dealers. The Supreme Judicial Court of Massachusetts in an advisory opinion given in I903, in considering this question, said that "it would be a perversion of the function of government for the state to enter as a competitor into the field of industrial enterprise, with a view either to the profit that could be made through the income to be derived from the business, or to the indirect gain that might result to purchasers if prices were reduced by governmental competition." "6 But that was in I903 and "times change" and with them the law of public purpose and municipal functions have changed.

${ }^{e 8}$ I82 Mass. 605, 66 N. E. 25 (1903). 
A thing may be a public purpose at one time and not be such at a later period. The New York and New Jersey legislatures in I9I7 authorized their cities to buy and sell food in time of emergency. The New York law was upheld by the Supreme Court of that state as a war emergency measure ${ }^{07}$ a thing which is valid only as an emergency measure at one time may become legal later, even in the absence of emergency, due to the changed economic conditions.

The extension of municipal functions has to a large degree come to be a question of public policy, subject to the final check of taxation only for a public purpose where public policy moves too fast. But in applying the check, the courts seem to have kept up with the spirit of the times and intervene only in exceptional cases. The attitude of the Supreme Court of the United States is to leave the matter to the states, and when the purpose is declared by the highest court of the state to be a public one, it will give great weight to that decision and interfere only in clearly arbitrary and unreasonable cases. "Times" and economic conditions will unquestionably change in the future and with them the law of public purpose and municipal functions.

"Howard v. City of New York, I99 App. Div. 596, I9I N. Y. Supp. 878 (1922); reversed on other grounds, 236 N. Y. 9 r, 140 N. E. 206 (I923). 